\title{
阮朝フエ王宮における隆徳殿の寸法計画について A STUDY ON THE SIZE PLAN OF LONG DUC DIEN AT HUE ROYAL PALACE IN NGUYEN DYNASTY
}

\author{
白井裕泰*, 中川 武** \\ Hiroyasu SHIRAI and Takeshi NAKAGAWA
}

\begin{abstract}
The conclusion of this paper is as follows. : We think that it was planned that after a whole scale is first assumed in Long Duc Dien, the edge pillars interval is set as a basic dimension, and the pillars interval was decided by the ratio of the pillars interval or the integral multiples of a unit length. Secondly, we think that the diameter of "mokoshi" pillar is set as a unit length, and the relation of the ratio of the pillars interval and the difference of the pillars interval exists between the each pillars interval when the pillars interval is decided according to a unit length. Thirdly, we think that the section size of Long Duc Dien was decided depending on the proportion coefficient $(1 / 2,1, \sqrt{2}, 5 / 3,2)$ being multiplied to the pillars interval.
\end{abstract}

Keywords: Size plan, Pillar interval plan, Section plan, Long Duc Dien, Nguyen Dynasty, Hue, Vietnam 寸法計画，柱間計画，断面計画，隆徳殿，阮朝，フエ，ヴィエトナム

\section{1.はじめに}

隆徳殿は、ユネスコ世界遺産(文 化遺産)「フエの建造物群」(1993 年登録)の1つであり、ヴィエト ナム最後の専制王朝であった阮朝 の宮殿建築である。

この建物の用途は、『大南実録』 によれば、明命 13 年(1832)の記事 ${ }^{1)}$ に、太廟の左に隆徳殿・昭敬殿、 右に (右方堂)・穆思殿があり、毎 年太祖皇帝皇后の命日に、供物を 供え、儀式を執り行っていたこと

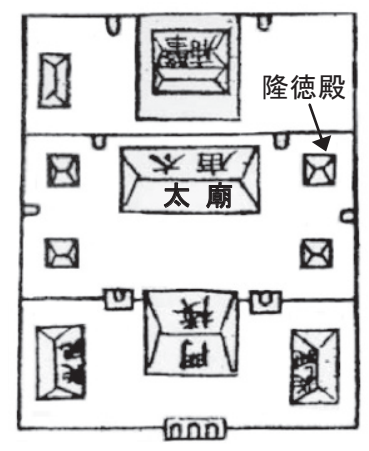

図 1 隆徳殿の位置 (大南一統志 (1909) による)

が窥われるので、隆徳殿は祠堂、昭敬殿は礼堂であったと考えられ る。

本論文は、2005～2008 年にかけて行われた（現在も継続して修復 工事が行われていて、2009 年度完了予定）隆徳殿の修復事業におい て得られた隆徳殿の実測寸法を資料として、隆徳殿の寸法計画、す なわち平面および断面の寸法計画を復原的に考察するものである。

\section{2. 隆徳殿の建築年代}

隆徳殿正面裳階東側壁の碑文 ${ }^{2)}$ によると、辛西年（1801）に阮氏 が北部地方を平定し、甲子年（1804）に都・村を造営し始め、皇城 の左方に太廟を嘉隆 3 年（1804） 3 月 15 日に着工し、10月 6 日に
竣工し、その記念にこの石碑を造立したことがわかる。したがって この石碑が当初から隆徳殿に埋め込まれたものであれば、隆徳殿の 建築年代は嘉隆 3 年（1804）ということになる。『欽定大南曾典事 例』によると、明命 12 年 $(1831)$ に修理 ${ }^{3)}$ し、『大南一統志』による と成泰 12 年(1900)に重放て修理 ${ }^{4)}$ したこと、また今回の修復工事

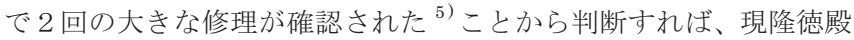
は創建当初のものと考えてよいであろう。

\section{3．構造形式および規模}

隆徳殿は，正面 5 間、側面 5 間、入母屋造、瓦莫き、木造平屋建 て、南面の建造物である。

内部空間は、中心に方一間の身舎（hàng nhất）空間があり、その 周囲に庇（hàng nhì）空間、さらに裳階（chái）空間を回した、いわ ゆる身舎 1 間 2 庇裳階付 $\left.{ }^{6}\right)$ の形式となっている。

正面裳階は吹き放しとし、1 間入側裳階・庇境には中央間・両脇 間に栈唐戸が建て込まれ、両端間は漆喰仕上げ煉瓦壁となっている。 また両側面および背面には漆喰仕上げ煉瓦壁が設けられている。 各柱は寸べて胴張りのある円柱であり、礎石の上に立っている。 ただし正面裳階柱中央 4 本は、礎石上に置かれた礎盤の上に立って いる ${ }^{7)}$ 。

内部架構は、中心に 4 本の身舎柱が飛貫・虹梁および頭貫で連結 された軸部があり、身舎梁行には合掌に組まれ、庇柱まで伸びた登 梁（ケオ）（kèo）を身舎柱で受け、拝み部に棟木（đòn đông）を載
*ものつくり大学技能工芸学部建設技能工芸学科 教授·工博

** 早稲田大学理工学術院建築学科 教授・博士 (工学)
Prof., Dept. of Building Technologists, Faculty of Technologists, Institute of Technologists, Dr. Eng.

Prof., Dept. of Architecture, Faculty of Science and Engineering, Waseda University, Dr. Eng. 
せている。合掌の扯み部には繋ぎの小梁 (áp quả) があり、大梁 (trến) 上に立つ枕木 (con dội) ・ 束柱（trụ đõ）で支えている。また身舎桁 行身舎柱上部に掛けられた母屋桁（đòn tay）とケオで構成される三 角形の妻部には妻板が張られている。

梁行の庇柱は、身舎柱に輪薙ぎ込まれ、中心まで伸びたケオを受 け、桁行および隅部は身舎柱に差し込まれた庇ケオを受け、各庇柱 は頭貫（xà đầu côt）および飛貫（xuyên trúng）で連結されている。 頭貫と飛貫の間には欄間（liên ba）板壁が嵌め込まれている。また 身舎虹梁の横面には陽刻の筋彫があり、両端に木鼻（đuôi kèo）が付 いている。身舎・庇のケオ横面にも陽刻の筋彫がある。

裳階柱は、庇柱に差し込まれた裳階ケ才を受け、各裳階柱は頭貫 で連結されている。また裳階ケオ・隅ケオの横面および下面には彫 刻が施され、先端は木鼻となっている。

ところで身舎柱・庇柱・裳階柱は、中心方向においてはケオのみ によって連結され、叉首組となっている身舎・庇の梁行方向のケオ を除いて、すべてケオは柄差し・蟻落し ${ }^{8)}$ であり、横力に対してき わめて脆弱な構造となっている。その構造の弱点を補強するために、 すべての身舎柱・庇柱・裳階柱は、内転びとなっている。

規模は、桁行総柱間 $12,577 \mathrm{~mm}$ 、梁行総柱間 $12,638 \mathrm{~mm}$ 、身舎軒の 出 $348 \mathrm{~mm}$ (各面軒の出の平均値)、身舎軒高さ $3,944 \mathrm{~mm}$ 、(各面軒高 さの平均值)、裳階軒の出 $588 \mathrm{~mm}$ (東 - 西 - 北面軒の出の平均值、 ただし南面軒の出は $710 \mathrm{~mm}$ )、裳階軒高さ $2,449 \mathrm{~mm}$ (各面軒高さの 平均値)、全高さ（礎石上端より大棟上端まで） $6,535 \mathrm{~mm}$ 、建築面積 $159.14 \mathrm{~m}^{2}$ となっている。

基壇の平面規模は東西 $13,702 \mathrm{~mm}$ 、南北 $13,757 \mathrm{~mm}$ で、地表から約 $18 \mathrm{~cm}$ 高くなっていて、南は葛石、東西北は幅 $150 \mathrm{~mm}$ 、長さ $300 \mathrm{~mm}$ 、 成 $60 \mathrm{~mm}$ の煉瓦を幅約 $61 \mathrm{~cm}$ に積んで形成されている。基壇上面塼 の下には砂利と瓦片が混ざったラテライト (約 $10 \mathrm{~cm}$ 厚)、土器片と 磁器片が混ざった粒子の大きい黄褐色砂質土 (約 $35 \mathrm{~cm}$ 厚)、粒子の 小さい砂が混ざった灰色粘質土（約 $12 \mathrm{~cm}$ 厚）、粒子が大きめの黄褐 色砂質土（約 $21 \mathrm{~cm}$ 厚）の順にほぼ水平に敷かれていた。礎石は、 一度砂質土を造ってから礎石部分の砂を掘り直して、固定したと考 えられる。

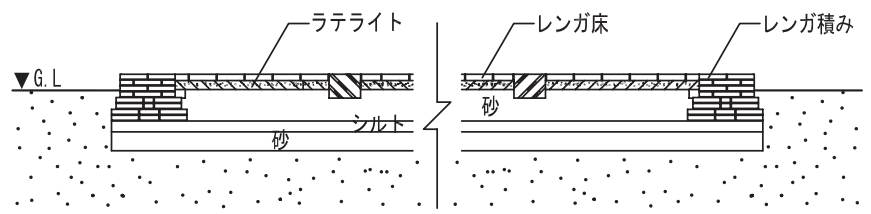

図 2 基壇現状断面図

\section{4. 平面寸法の分析}

隆徳殿の柱間寸法は、まず礎石位置を実測し、礎石と柱の位置関 係を実測し、さらに柱径を実測し、（柱間内法寸法十両端柱半径）に よって柱心々寸法を算出した。この実測寸法を資料として、柱間計 画について考察を試みることにする。

\section{4-1＼cjkstart礎石レベル}

礎石のレベル（図 3 参照）をみると、東北隅の $6 \mathrm{~F}$ 礎石が最も高 く、その点を基準にすれば, 西南隅の $1 \mathrm{~A}$ 礎石で最大 $48 \mathrm{~mm}$ 低く、 続いて西南部の $2 \mathrm{~A}$ 礎石 $(-45 \mathrm{~mm}) 、 3 \mathrm{~A}$ 礎石 $(-41 \mathrm{~mm})$ 、西北部
の $3 \mathrm{~F}$ 礎石 $(-42 \mathrm{~mm}) 、 1 \mathrm{E}$ 礎石 $(-38 \mathrm{~mm})$ 、東南部の 6 B 礎石 $(-$ $33 \mathrm{~mm})$ が低く，相対的に西南部および西北部の礎石が沈下してい ることがわかる。

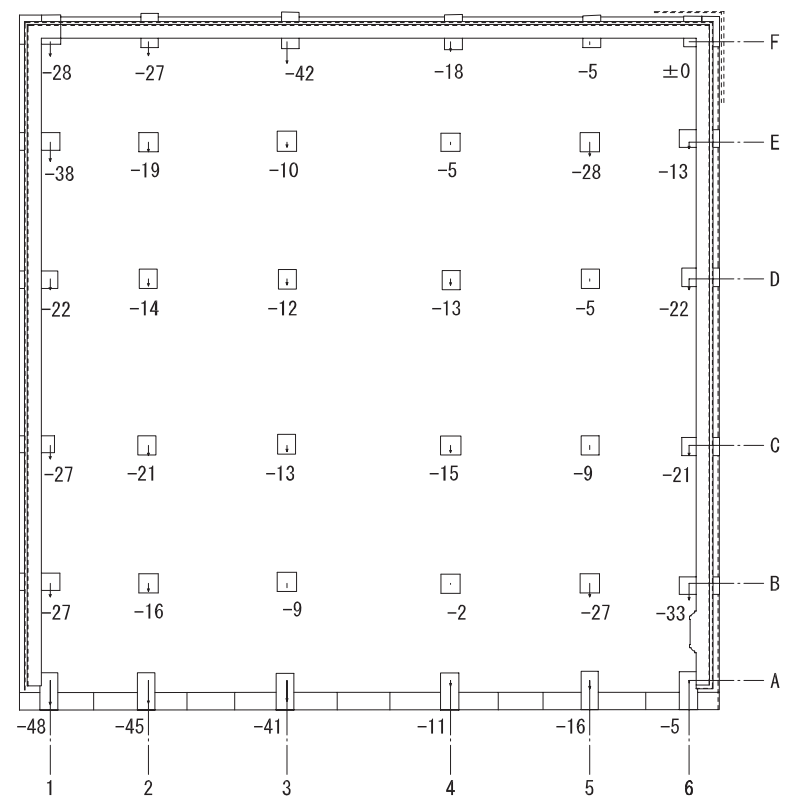

図 3 礎石レベル図

礎石の不同沈下は、柱上部が飛貫・頭貫によって固められている ので、直接的には柱間寸法に大きく影響を及ぼすものではないと考 えられる。

\section{4-2 柱間寸法}

礎石上端高さにおける柱間寸法および柱径、桁行および梁行方向 の中間・脇間・端間の平均寸法值を示したものが図 4 である。

さらに各柱間の寸法值を官木尺 $(1 \text { 尺 }=424 \mathrm{~mm})^{9)}$ で換算した寸 法值を示したものが表 $1 \cdot 2$ である。

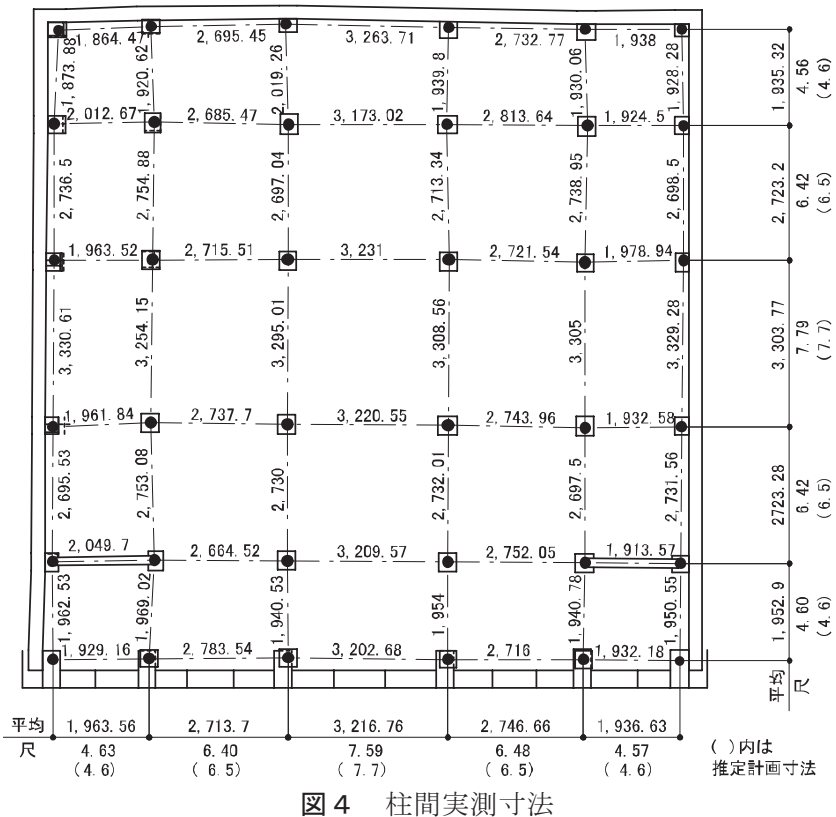

図 4 柱間実測寸法 
表 1 柱間寸法・柱間比・柱径比（桁行方向）

\begin{tabular}{|c|c|c|c|c|c|c|c|}
\hline & 端 間 & $\begin{array}{l}\text { 脇 間 } \\
\end{array}$ & 中間 & 脇 間 & 端 間 & 総 間 & 備 考 \\
\hline 実測寸法 & 1963.6 & 2713.7 & 3216.8 & 2746.7 & 1936.6 & 12577.4 & 平均値 \\
\hline 官木尺換算 & 4.63 & 6.4 & 7.59 & 6.48 & 4.57 & 29.67 & 1 尺 $=424 \mathrm{~mm}$ \\
\hline 柱間比 & 1 & 1.39 & 1.65 & 1.41 & 0.99 & & 端間=4.6尺 \\
\hline 身舎柱径比 & 8.9 & 12.3 & 14.6 & 12.5 & 8.8 & & 身舎柱径 $=0.53$ 尺 \\
\hline 庇柱径比 & 9.4 & 13.1 & 15.5 & 13.2 & 9.3 & & 庇柱径 $=0.5$ 尺 \\
\hline 裳階柱径比 & 10.1 & 13.9 & 16.5 & 14.1 & 9.9 & & 裳階柱径 $=0.47$ 尺 \\
\hline
\end{tabular}

表 2 柱間寸法・柱間比・柱径比（梁行方向）

\begin{tabular}{|l|r|r|r|r|r|r|l|}
\hline & 端 間 & 脇 間 & \multicolumn{1}{c|}{ 中 間 } & 脇 間 & 端 間 & 総 間 & 備 考 \\
\hline 実測寸法 & 1952.9 & 2723.3 & 3303.8 & 2723.2 & 1935.3 & 12638.5 & 平均値 \\
\hline 官木尺換算 & 4.61 & 6.42 & 7.79 & 6.42 & 4.56 & 29.8 & 1 尺 $=424 \mathrm{~mm}$ \\
\hline 柱間比 & 1 & 1.4 & 1.69 & 1.4 & 0.99 & & 端間=4.6尺 \\
\hline 身舎柱径比 & 8.9 & 12.3 & 15 & 12.3 & 8.8 & & 身舎柱径 $=0.53$ 尺 \\
\hline 庇柱径比 & 9.4 & 13.1 & 15.9 & 13.1 & 9.3 & & 庇柱径=0.5尺 \\
\hline 裳階柱径比 & 10 & 14 & 16.9 & 14 & 9.9 & & 裳階柱径=0.47尺 \\
\hline
\end{tabular}

この表をみると、当初の隆徳殿の柱間寸法は端間 4.6 尺、脇間 6.4 ～6.5 尺、中間 $7.6 \sim 7.8$ 尺、すなわち端間 4.6 尺、脇間 6.5 尺、中

間 7.7 尺であったと推定される。

また総柱間は、

桁行方向 : $4.6+6.4+7.6+6.5+4.6=29.7$ (尺)

梁行方向 : $4.6+6.4+7.8+6.4+4.6=29.8$ (尺)

となり、当初の全体規模は 30 尺×30 尺で計画された可能性がある $10)$

\section{4-3 柱径}

柱径の実測寸法を示したのが表 3 である。この表より、身舎柱・ 庇柱・裳階柱の下径の平均值を求めると、身舎柱径 $=225 \mathrm{~mm}$ 、庇柱 径 $=211 \mathrm{~mm}$ 、裳階柱径 $=199 \mathrm{~mm}$ であり、官木尺に換算すると、身 舎柱径 $=0.53$ 尺、庇柱径 $=0.5$ 尺、裳階柱径 $=0.47$ 尺となる。

身舎柱・庇柱・裳階柱の関係をみると、庇柱径は裳階柱径の 3 分 増し、身舎柱径は庇柱径の 3 分増しとなっていることがわかる。

表 3 柱径実測寸法（単位：mm）

\begin{tabular}{|l|r|r|r|r|r|r|}
\hline & 1 & \multicolumn{1}{|c|}{2} & 3 & \multicolumn{1}{l|}{4} & \multicolumn{1}{l|}{5} & \multicolumn{1}{c|}{6} \\
\hline A & 199 & 192 & 209 & 197 & 190 & 197 \\
& 200 & 204 & 210 & 207 & 202 & 198 \\
\hline B & 205 & 211 & 211 & 205 & 200 & 199 \\
& 199 & 204 & 202 & 211 & 213 & 199 \\
\hline C & 192 & 207 & 221 & 230 & 198 & 186 \\
& 200 & 215 & 220 & 238 & 197 & 193 \\
\hline D & 189 & 216 & 222 & 225 & 216 & 187 \\
& 201 & 214 & 227 & 225 & 211 & 201 \\
\hline E & 189 & 214 & 210 & 210 & 209 & 191 \\
& 206 & 210 & 216 & 229 & 211 & 191 \\
\hline F & 193 & 183 & 192 & 189 & 185 & 193 \\
& 197 & 188 & 192 & 191 & 197 & 197 \\
\hline
\end{tabular}

表注 1：上段/上径（ケオ下端位置） 下段/下径（礎石より高さ $1 \mathrm{~m}$ 位置）

表注 $2: \mathrm{B}$ 列 /解体後実測值 $\mathrm{B}$ 列以外 /解体前実測值

\section{4-4 柱間計画 ${ }^{11}$}

隆徳殿の柱間寸法はどのように決定されたのであろうか。柱間計 画法として各柱間相互の比例で決定する方法と各柱間を単位長の整 数倍で決定する方法が考えられる ${ }^{12)}$ 。

\section{4-4. 1 柱間比による柱間計画}

柱間比による柱間計画法を検討するために、各間の推定柱間寸法 值の比例值を求めてみる。

端間：脇間：中間 $=4.6: 6.5: 7.7$

$$
=1: 1.413: 1.674
$$

となり、 1.413 は $1.414=\sqrt{ } 2 、 1.67$ は $5 / 3$ の比例值に近いことがわ かる。

すなわち各間の比例値は、端間を基準にすれば、
端間：脇間 : 中間 $=1: \sqrt{ } 2: 5 / 3$

となる。この比例值は図 5 のように求めることができる。

(1) $\mathrm{AB}$ を端間の寸法 4.6 尺とする。

(2) $\mathrm{AC}$ を $\mathrm{AB}$ 上に重ねれば、 $\mathrm{AE}=\mathrm{AC}=\sqrt{ } 2 \mathrm{AB}=\sqrt{ } 2 \times 4.6=6.505$ （尺）となる。

(3) $\mathrm{A}$ から 3 尺の位置を $\mathrm{F} 、 \mathrm{~F}$ から $\mathrm{AB}$ に垂直に 4 尺の位置を $\mathrm{G}$ と すれば、 $\mathrm{AF}: \mathrm{FG}: \mathrm{AG}=3: 4: 5$ となる。

(3) $\mathrm{AG}$ を延長し、 $\mathrm{BC}$ の延長線との交点を $\mathrm{H}$ とし、 $\mathrm{AB}$ 上に重ね れば、 $\mathrm{AI}=\mathrm{AH}=5 / 3 \mathrm{AB}=5 / 3 \times 4.6=7.67$ (尺) となる。 したがって、 $\mathrm{AB}: \mathrm{AE}: \mathrm{AI}=$ 端間 : 脇間 : 中間 $=1: \sqrt{ } 2: 5 / 3$ と なり、隆徳殿の推定柱間計画寸法は、端間 : 脇間 : 中間 $=4.6$ 尺：6.5 尺： 7.7 尺 と考えることができる。

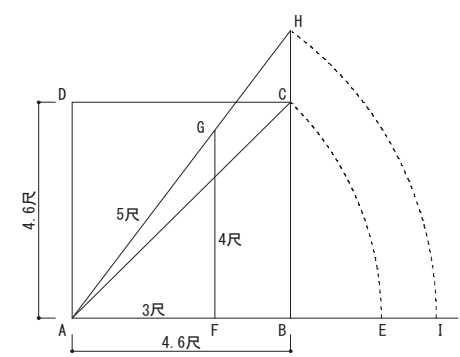

図 5 柱間比算

\section{4-4. 2 単位長 ${ }^{13)}$ (=柱径) による柱間計画}

柱径を単位長と想定したとき、各柱間は表 $1 \cdot 2$ のように表され る。この表をみると、単位長として裳階柱径 $=0.46$ 尺 ${ }^{14)}$ とすれば、 梁行方向の柱間は、

端間：脇間：中間＝10(または 9.9) : 14: 16.9

$$
\doteqdot 10: 14: 17
$$

となり、各柱間が単位長（u）の整数倍によって表されることがわ かる。

ところで $10 ・ 14 \cdot 17$ という数字がどのような意味をもつのであ ろうか。まず端間が $10 u$ であるということは、裳階柱の 10 倍が端 間である、すなわち端間の $1 / 10$ が裳階柱径であることを意味してい る。次に脇間の $14 \mathrm{u}$ であるが、端間に対して $4 \mathrm{u}$ (裳階柱 4 本) の 差がある。さらに中間 $17 \mathrm{u}$ は脇間 $14 \mathrm{u}$ に対して $3 \mathrm{u}$ (裳階柱 3 本) の差がある。つまり各柱間は端間を基準に柱間差によって決定され ていると考えることができる。

$10 \cdot 14 \cdot 17$ の数字の意味としてもう 1 つ考えられる。それは $14 / 10$ $=1.4 \fallingdotseq \sqrt{ } 2$ であり、 $17 / 10=1.7 \fallingdotseq 5 / 3$ であるから前項で考察した柱間 比が背景に隠されていると考えることもできる。

\section{4-4. 3 柱間決定の手順}

ところで柱間寸法を決定する手順はどのように考えられるだろう か。ここに 2 つの仮説を示すことにする。

\section{仮説 $1:$ 柱間比による柱間計画}

1 ）隆徳殿の全体規模を 30 尺×30 尺とする。この規模は王宮の全 体規模との関係から決定されると考えられる。

2 ）各柱間は $1: \sqrt{ } 2: 5 / 3$ の比例で分割する。

3 ）基準柱間である端間は、30 尺 $(1+1.41+1.67+1.41+1)=$ 30 尺 $\div 6.49=4.62$ 尺となり、 4.6 尺と決定される。

4 ）脇間は 4.6 尺 $\times \sqrt{ } 2=6.505$ 尺 $\fallingdotseq 6.5$ 尺、中間は 4.6 尺 $\times 5 / 3=$ 
7.667 尺う7.7 尺となり、各柱間が決定される。

5 ) 柱径は裳階柱が端間の $1 / 10$ 、すなわち 4.6 尺 $\times 1 / 10=0.46$ 尺と 決定される。

6 ) 庇柱径は裳階柱径の 3 分増しで 0.49 尺、身舎柱径は庇柱径の 3 分増しで 0.52 尺と決定される。

\section{仮説 2：単位長による柱間計画}

1）隆徳殿の全体規模を 30 尺 $\times 30$ 尺とする。

2 ) 単位長 $\mathrm{u}$ を裳階柱径 $=0.46$ 尺とする。

3 ) 総柱間は $30 \div 0.46=65.2$ から $65 u$ とし、端間を $10 u=4.6$ 尺と 決定する。

4）脇間は端間に裳階柱 4 本増し、寸なわち $10 u+4 u=14 u=6.44$ 尺とする。中間は脇間に裳階柱 3 本増し、すなわち $14 \mathrm{u}+3 \mathrm{u}=$ $17 \mathrm{u}=7.82$ 尺とする。

5 ）脇間・中間は仮説 1 の柱間比を想定して、その近似值である $14 \mathrm{u} \cdot 17 \mathrm{u}$ を採用した可能性もある。

6 ) 庇柱径と身舎柱径は仮説 1 と同様に決定される。

\section{5. 断面寸法の分析}

隆徳殿の断面寸法は、梁行が 3 通り、桁行が C 通りを実測した。 断面の実測箇所は、礎石上端より裳階柱上端、庇柱上端、身舎柱上 端、庇柱筋飛貫下端、身舎柱筋大梁（桁行 - 梁行）下端、棟木下端 を実測した。

\section{5-1 断面寸法}

桁行（C通り）と梁行（3 通り）の主要断面寸法を示したものが 図 $6 \cdot 7$ であり、また参考のために柱高さの実測寸法を示したもの が表 4 である。

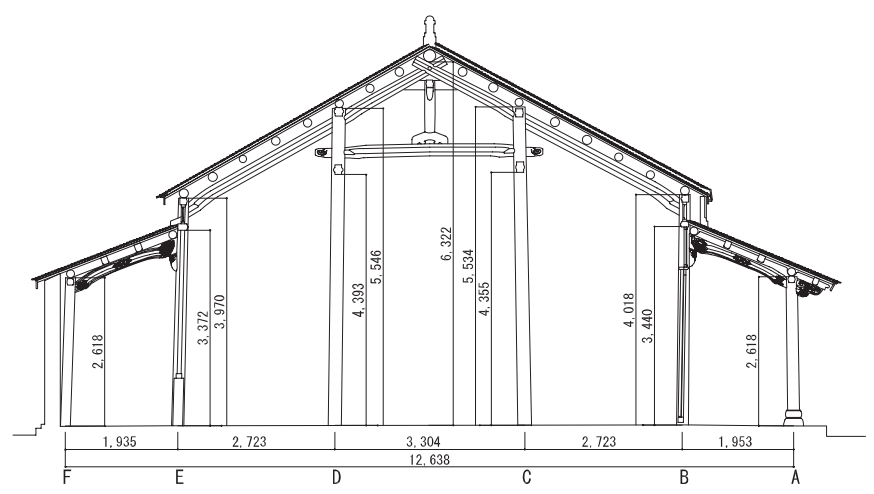

図 6 隆徳殿 3 通り断面図

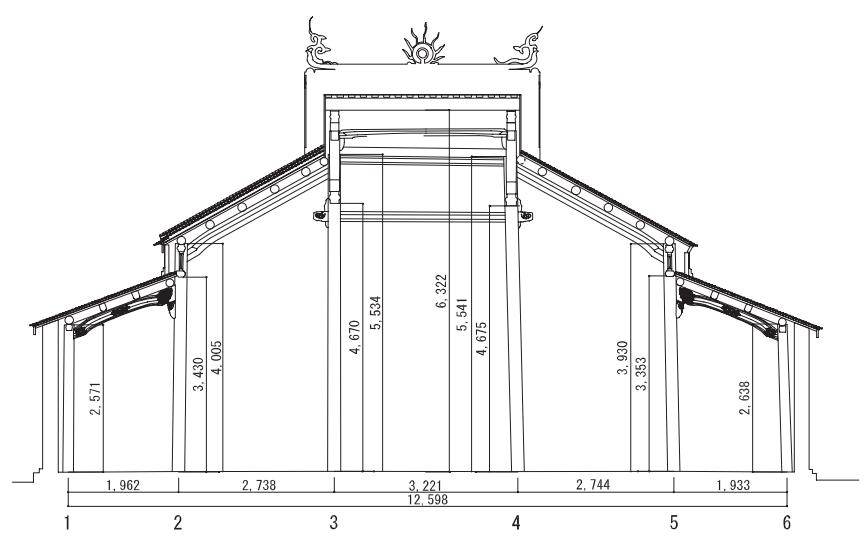

図 7 隆徳殿 C 通り断面図
表 4 柱高さ実測寸法（単位：mm)

\begin{tabular}{|r|r|r|r|r|r|r|}
\hline & \multicolumn{1}{|c|}{1} & \multicolumn{1}{c|}{2} & \multicolumn{1}{c|}{3} & \multicolumn{1}{c|}{4} & \multicolumn{1}{c|}{5} & \multicolumn{1}{c|}{6} \\
\hline A & 2,685 & 2,645 & 2,618 & 2,590 & 2,611 & 2,624 \\
\hline B & 2,645 & 4,027 & 4,018 & 4,006 & 4,057 & 2,638 \\
\hline C & 2,571 & 4,005 & 5,534 & 5,541 & 3,930 & 2,638 \\
\hline D & 2,579 & 3,989 & 5,546 & 5,516 & 3,976 & 2,584 \\
\hline E & 2,645 & 4,059 & 3,970 & 3,956 & 4,062 & 2,626 \\
\hline F & 2,683 & 2,612 & 2,618 & 2,583 & 2,628 & 2,676 \\
\hline
\end{tabular}

この図より梁行と桁行の主要断面寸法の平均值を求める ${ }^{15)}$ と、 大棟高さは $6,322 \mathrm{~mm}$ (14.9 尺)、身舎柱高さは $5,539 \mathrm{~mm}$ (13.1 尺)、 庇柱高さは $3,981 \mathrm{~mm}$ (9.4 尺)、裳階柱高さは $2,611 \mathrm{~mm}$ (6.2 尺)、庇 柱筋飛貫下端高さは $3,399 \mathrm{~mm}$ (8 尺)、桁行大梁下端高さは $4,374 \mathrm{~mm}$

(10.3 尺)、梁行大梁下端高さは $4,673 \mathrm{~mm}$ （11 尺）であった。

\section{5-2 断面計画 ${ }^{16)}$}

まず身舎柱高さ、庇柱高さ、裳階柱高さをどのように決定したの であろうか。1つの可能性として、次のような計画法が想定される。

図 8 によれば、身舎柱高さは脇間の 2 倍 $(\mathrm{bj}=2 \mathrm{bg}=2 \times 2,723=$ $5,446 \mathrm{~mm})$ 、庇柱高さは脇間の $\sqrt{2}$ 倍 $(\mathrm{go}=\sqrt{ } 2 \mathrm{bg}=\sqrt{ } 2 \times 2,723=3,851$ $\mathrm{mm}) 、$ 裳階柱高さは端間の $\sqrt{2}$ 倍 $(\mathrm{gh}=\sqrt{2} \mathrm{gl}=\sqrt{2} \times 1,944=2,749 \mathrm{~mm})$ に近似していることがわかる。

また棟木下端高さは $1 / 2$ 中間 + 脇間 + 端間 $=1 / 2$ 総間 $(r s=1 / 2 q 1$ $=1 / 2 \times 12,638=6,319 \mathrm{~mm})$ 、梁行大梁下端高さは脇間 + 端間 $(\mathrm{au}=$ $\mathrm{aq}=2,723+1,944=4,667 \mathrm{~mm}) 、$ 桁行大梁下端高さは $1 / 2$ 中間 + 脇間 $(\mathrm{bx}=\mathrm{rw}=1 / 2 \mathrm{ab}+\mathrm{av}=1 / 2 \times 3,304+2,723=4,375 \mathrm{~mm})$ 、庇柱筋飛 貫下端高さは中間（ $\mathrm{ad}=\mathrm{ab}=3,304 \mathrm{~mm} ）$ に近似している。

このうち棟木下端高さ（計画寸法と実測寸法の誤差 $-3 \mathrm{~mm}$ )、梁行 大梁下端高さ (誤差 $-6 \mathrm{~mm}$ )、桁行大梁下端高さ（誤差 $1 \mathrm{~mm}$ ）は、ほ ぼ計画寸法と実測寸法が一致する。しかし身舎柱高さ (誤差一 $93 \mathrm{~mm}$ )、 庇柱高さ（誤差－130 mm）、裳階柱高さ（誤差 $138 \mathrm{~mm}$ ）、庇柱筋飛貫 下端高さ（誤差－95 mm）はいずれも誤差が大きすぎる。

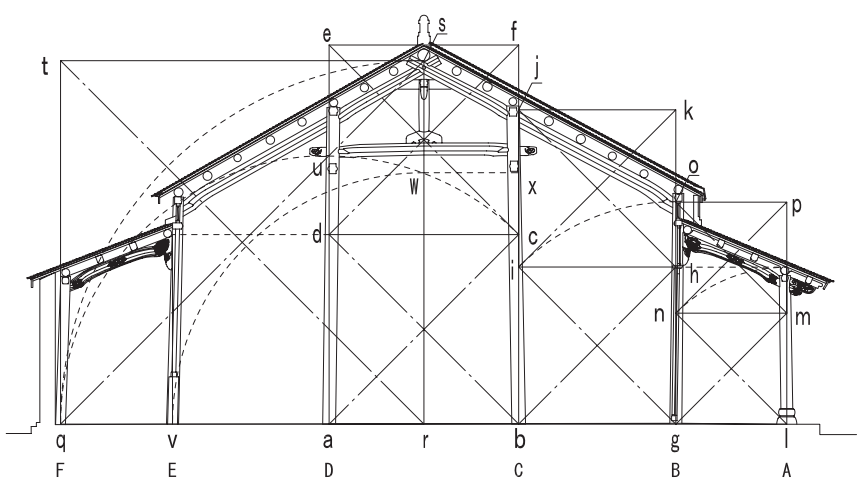

図 8 隆徳殿 梁行断面計画図 1

この誤差の大きさを解消するために、図 9 のように、中間・脇間・ 端間の心々寸法を（柱心〜柱内寸法）、（柱心〜柱外寸法）に置き換 えて調整してみると以下のようになる。

庇柱高さは（庇柱心～身舎柱外寸法）の $\sqrt{2}$ 倍、すなわち $\sqrt{ } 2 \mathrm{gb} 1=$ $\sqrt{ } 2($ 脇間 $+1 / 2$ 身舎柱径 $)=\sqrt{ } 2(2,723+1 / 2 \times 220)=\sqrt{ } 2 \times 2,833=$ $4,006 \mathrm{~mm}$ で、誤差は $25 \mathrm{~mm}$ となる。

裳階柱高さは（裳階柱心〜庇柱内寸法）の $\sqrt{2}$ 倍、すなわち $\sqrt{ } 2 \lg 1$ $=\sqrt{ } 2($ 端間 $-1 / 2$ 庇柱径 $)=\sqrt{ } 2(1,944-1 / 2 \times 208)=\sqrt{ } 2 \times 1,840=$ 
$2,602 \mathrm{~mm}$ で、誤差は $-9 \mathrm{~mm}$ となる。

庇柱筋飛貫下端高さは（身舎柱心～身舎柱外寸法）と同じ、すな わち中間 $+1 / 2$ 身舎柱径 $=3,304+1 / 2 \times 220=3,414 \mathrm{~mm}$ で、誤差は一 $15 \mathrm{~mm}$ となる。

また身舎柱高さは、端間 $\times 5 / 3=$ 中間の関係と同様の方法で決定す る。 $3 \mathrm{~m} \times 4 \mathrm{~m} \times 5 \mathrm{~m}$ の直角三角形 $\triangle \mathrm{aa}_{1} \mathrm{a}_{2}$ を $\mathrm{ab}$ 上に設定し、 $\mathrm{aa}_{2}$ を延 長し、bjとの交点を $a_{3}$ とすれば、身舎柱高さ $a a_{4}$ は $a a_{3}$ と同じ、す なわち $\mathrm{aa}_{4}=\mathrm{aa}_{3}=\mathrm{ab} \times 5 / 3=$ 中間 $\times 5 / 3=3,304 \times 5 / 3=5,507 \mathrm{~mm}$ )で、 誤差は $32 \mathrm{~mm}$ となる。

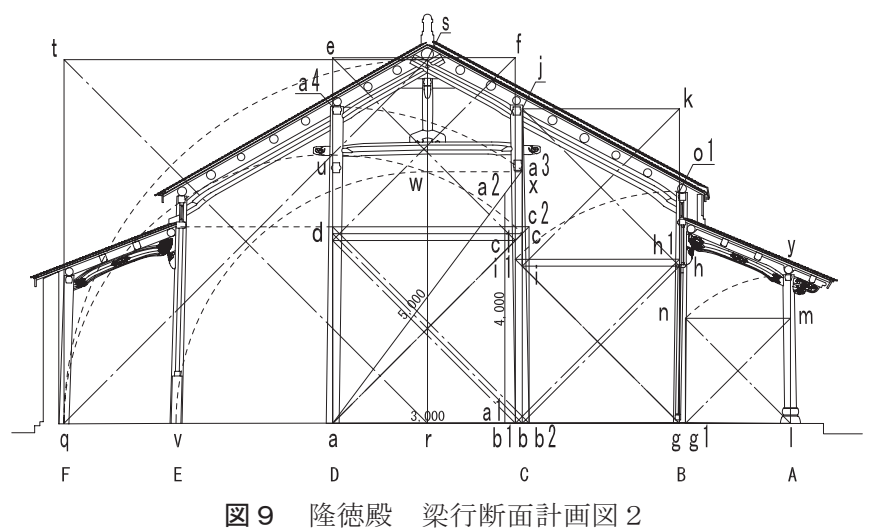

このように隆徳殿の断面計画は、棟木下端高さは総間 $\times 1 / 2$ 、身舎 柱高さは中間 $\times 5 / 3$ 、庇柱高さは（庇柱心～身舎柱外寸法） $\times \sqrt{2}$ 、裳 階柱高さは（裳階柱心～庇柱内寸法） $\times \sqrt{ } 2$ 、庇柱筋飛貫下端高さは （身舎柱心〜身舎柱外法）と同じと考えることができる。

\section{6. おわりに}

隆徳殿の柱間寸法は、まず全体規模を想定し、基準寸法として端 間を設定した上で、柱間比または単位長の整数倍によって計画され たと考えることができる。単位長によって柱間を決定する場合、単 位長として裳階柱が設定され、各柱間相互に柱間差と柱間比の関係 が内在していると考えることができる。

また隆徳殿の断面寸法は、柱間 $\times$ 比例係数 $(1 / 2 、 1 、 \sqrt{ } 2 、 5 / 3$ 、 2 ）によって決定されたと考えることができる。

なお本稿は、平成 $17-20$ 年度日本学術振興会科学研究費 (基盤研究 A)「阮 朝・太廟・隆徳殿の修復計画一ヴィエトナムの文化遺産（建造物）の保存に 関する技術移転の確立と国際協力一」(研究代表者・ものつくり大学教授白井 裕泰) の成果の一部である。またこのプロジェクトは、早稲田大学ユネスコ 世界遺産研究所（代表者・早稲田大学教授中川武）および省立フ工遺跡保存 センター (所長フン・フー) と共同で推進しており、平成 15-18 年度日本 学術振興会科学研究費補助金 (基盤研究 S)「乾成宮の復原的研究一ユネスコ 世界遺産・フエの歴史的建造物群の保全計画一」および平成 $19-20$ 年度日 本学術振興会科学研究費補助金 (基盤研究 S)「阮朝王宮の歴史的環境の復原 - CG 技術を活用した再現と GIS 構築一」(研究代表者・中川武)、平成 1520 年度文部科学省補助事業 - 私立大学学術研究高度化推進事業 (学術フロン ティア推進事業）「ユネスコ世界遺産・フエ遺跡群とその環境の保全及び宮廷 音楽等無形文化遺産の保護・振興」（研究代表者・中川武）の一環として行わ れたものである。

また本稿は、白井裕泰「隆徳殿の柱間計画について一阮朝・太廟・隆徳殿 の修復計画 (その 1$) 」($ 日本建築学会学術講演梗概集、2006 年、pp.283-284) および白井裕泰・中川武「隆徳殿の断面計画について一阮朝・太廟・隆徳殿
の修復計画 (その 5 )」(日本建築学会学術講演梗概集、2007 年、pp.177-178) として発表済である。

注

1)『大南実録』(正編 第二紀 巻七十九 頁二十八) 明命 13 年(1832)の 記事に「太廟之左榮草隆徳殿遞年恭遇太祖嘉裕皇帝皇后忌辰祇奉陳設行 禮」とある。

2）隆徳殿正面東側壁の石碑に下記のように刻まれている。

3）『欽定大南會典事例』（工部 巻二百八 頁八）明命 13 年の記事に「太 廟左方殿（隆徳殿）著重加修飭改莫琉璃瓦」とある。

4)『大南一統志』(巻一 京師 頁八) に「隆德殿舊左方堂召 敬穆思舊左右祭所明命十三 年均改今名成泰十二年重修」 とある。

5）解体した垂木を観察すると、 下屋垂木の下面にほとんど 面がなく、上屋垂木の下面に は面があり、下屋垂木のほと んどが取り替えられたこと がわかる。また上屋垂木の幅 をみると、(1) $100-110 \mathrm{~mm}$ (2) 115-125mm (3) $130-140 \mathrm{~mm}$ の 3 群に分けられる。面のな い下屋垂木の幅が 100-110mm に集中している ことから、100-110mm の上 屋垂木は取替量の多さから 考えて成泰 12 年に取り替え られたものであろう。また修 理ごとに垂木幅を小さくし たとすれば、幅 130-140mm が創建当初の垂木であり、幅 115-125mm の垂木は明命 13 年に取り替えられたもの と考えられる。

6）重枝豊他「フエ宮廷建築の平 面表記について ヴェトナ ム・フエの明命帝陵の総合調

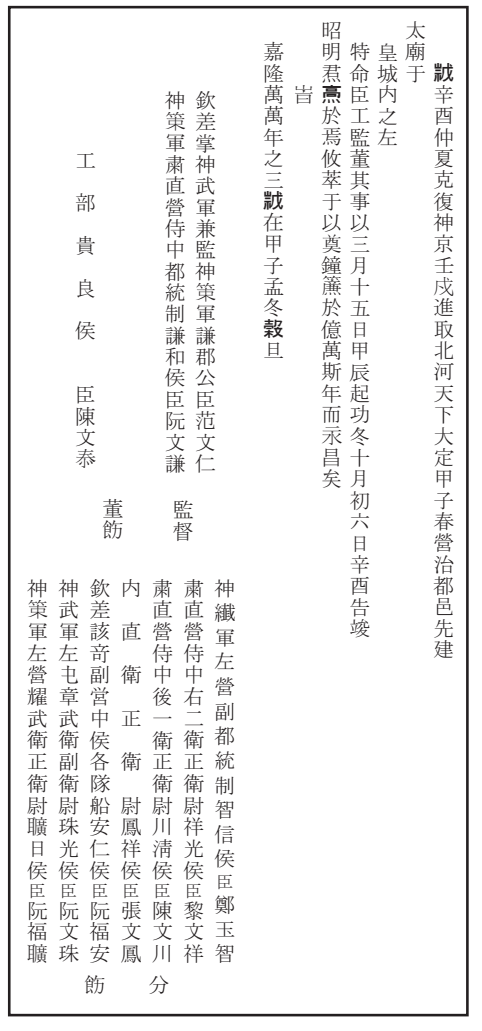
查その $1 」(日$ 本建築学会学術講演梗概集 F-2, pp.487-488, 1996) によ ると、この形式を 1 間 2 廈回廊付 (1 gain 2 chái hoi lang) と呼んでい る。

7）解体調查の結果、礎石上面に丸柱の痕跡が残っていたので、正面裳階柱 中央 4 本の下部にある礎盤は後補のものであり、当初は䃈石上に柱が直 接立っていたことがわかる。

8）ただし庇隅ケオは、身舎柱に突き付けで、持ち送り（コン・ボー）で受 けていた。

9）小榑哲央 $\cdot$ 中川武 $\cdot$ 西本真一 $\cdot$ 中沢信一郎 $\cdot$ 土屋武 $\cdot$ 坂本忠規 $\cdot$ 白井裕 泰・高野恵子「阮朝宫殿建築造営に用いられる尺度について ヴィエト ナム/フエ・阮朝王宮の復原的研究（その 25）」（日本建築学会学術講演 梗概集 F-2, pp.171-172, 1999) において、(1)史料と実測值による分析(2) 紫禁城・皇城の配置寸法計画の分析による尺度の推定(3)現存する阮朝の ものさしからの換算値による検定の結果、官木尺（1 尺 $=424 \mathrm{~mm} ） お$ お び魯班尺（1 尺 $=384 \mathrm{~mm} ）$ と規定している。

10）中沢信一郎 - 中川武 - 西本真一 ・土屋武 - 坂本忠規 $\cdot$ 白井裕泰 $\cdot$ 高野恵 子「太廟区・世廟区の配置計画について（II） ヴィエトナム/フェ・ 阮朝王宮の復原的研究 (その 22)」(日本建築学会学術講演梗概集 F-2, pp.165-166, 1999）によると、太廟区の規模が東西 30 丈、南北 37.25 丈

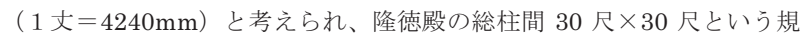
模は、太廟区東西 30 丈の $1 / 10$ として決定された可能性がある。

11）従来、日本古代建築の柱間は、完数尺の柱間比によって決定されたとす る考え（関野貞『法隆寺金堂塔婆及中門非再建論』(1905 年)による) が定説であったが、石井邦信氏は『日本古代建築における寸法計画の研 究』(早稲田大学学位論文、1975 年) において、日本古代建築の柱間相 互の関係には、柱間差と単位長 (=柱半径近傍) との間に密接な関係が 存在することを明らかにした。 
12）これまでの阮朝宮殿建築の平面計画の分析をみると、佐々木太清・中川 武・西本真一 - 中沢信一郎 · 白井裕泰 - 高野恵子 - 土屋武 · 富樫洋之 · 石原彩子・柳下敦彦「肇廟の構造形式と平面計画における単位長につい て ヴィエトナム/フエ・阮朝王宮の復原的研究（その9)」（日本建築 学会学術講演梗概集 F-2, pp.471-472, 1997）によると、肇廟は「柱の平 均半径である $174.5 \mathrm{~mm}$ を $\mathrm{u}$ とすれば、中間、左右脇間一、左右脇間二、 左右端間は近似的にそれぞれ $22 \mathrm{u} 、 20 \mathrm{u} 、 17 \mathrm{u} 、 15 \mathrm{u}$ という值が得ら れ、正面柱間における中間とその他の柱間との中脇差は、左右脇間一で 正楹庇側柱直径一本分の $2 \mathrm{u}$ 、左右脇間二で $3 \mathrm{u}$ 、左右裳階で $2 \mathrm{u}$ とな る」と報告され、柱間寸法が柱間差で決定されていることを明らかにし ている。同様に富樫洋之 ・ 中川武 - 西本真一 - 中沢信一郎 - 白井裕泰 高野恵子・土屋武・石原彩子・佐々木太清・柳下敦彦「興廟の構造形式 と平面計画における単位長について ヴィエトナム/フエ・阮朝王宮の 復原的研究（その 10）」（日本建築学会学術講演梗概集 F-2, pp.471-472, 1997）によると、興廟の柱間寸法も柱間差で決定されていると指摘され ている。また土屋武・中川武・西本真一 - 中沢信一郎 - 白井裕泰 ·高野 恵子・佐々木太清 ・ 小槫哲央高木直人 ・ 柳下敦彦 - 山内健太 ・ 山岸直子 川嶋彩「延寿宮正殿の寸法計画の分析 ヴィエトナム/フエ・阮朝王宮 の復原的研究 (その 14)」(日本建築学会学術講演梗概集 F-2, pp.163-164 1998）によると、延寿宮の平面計画は、正楹梁間を尺単位で指定したの ち、母屋桁間隔を単位長として簡単な整数比で決定されていると指摘さ
れている。

13）前掲 12)の文献によると、肇廟の平面計画における単位長として正楹庇 側柱および前楹身舎柱の半径、興廟の平面計画における単位長として前 楹柱、正楹庇柱の半径、延寿宮正殿の平面計画における単位長として母 屋桁間隔を想定している。

14）裳階柱の平均柱径は 0.47 尺であるが、ここでは単位長として裳階柱径を 0.46 尺と仮定した。

15）表 4 における柱高さの平均值は、中間両端の全身舎柱高さの平均值が $5534 \mathrm{~mm}$ 、中間両端の全庇柱高さの平均值が $3981 \mathrm{~mm}$ 、中間両端の全裳階 柱高さの平均值が $2598 \mathrm{~mm}$ であり、C通りと 3 通りのそれぞれの柱高さ の平均值とそれほど大きな差は認められない。

16）阮朝王宮における宮殿建築の断面計画について考察したものとして 佐々木太清 - 中川武 - 西本真一 ・ 中沢信一郎 - 白井裕泰 - 高野恵子 · 土 屋武・柳下敦彦・小槫哲央・高木直人・山内健太・山岸直子・川嶋彩「肇 廟の断面計画について ヴィエトナム／フエ・阮朝王宮の復原的研究 (そ の 15)」(日本建築学会学術講演梗概集 F-2, pp.165-166, 1998) において 「正楹身舎梁間を 1 として、裳階屋根最上部、前楹棟、正楹棟高さを 1 ： $1.5: 2$ という単純な比率により決定されている」と指摘されている。

（2008年12月10日原稿受理，2009年 6 月11日採用決定） 